\title{
Kebijakan Pemimpin Pondok Pesantren Hidayaul Mubtadi'in Kembang Singosari Malang Dalam Pengembangan Pendidikan Formal
}

\author{
Mirza Nur Alimi \\ STAI “Ma'had Aly Al-Hikam” Malang, Indonesia
}

\begin{abstract}
In educational institutions, both formal and nonformal, the policy of a leader becomes the center of discussion and attention of experts, namely in terms of science itself and other sciences. Based on these facts, especially those related to the policies of the boarding school leaders have the right to all authority and responsibility that exist in the foundation, especially in formal education under its auspices. Therefore it is necessary to re-examine the policies of the Islamic boarding school leaders in the development of formal education, so that in the development of education it is not only in Islamic boarding school education.
\end{abstract}

Based on the cases taken, the formulation of the research problem is to describe how the policies of the leader of the Islamic boarding school Hidayaul Mubtadi'in Kembang in the development of formal education, and to describe how the policy making process of the leader of the Islamic boarding school Hidayaul Mubtadi'in Kembang in the development of formal education. This research is a qualitative research. Data collection was carried out by conducting observations, interviews and documentation. Data analysis was carried out by collecting data which was then selected and simplified according to the research findings, by presenting data that could be drawn conclusions. In this study, the data validity checking techniques used were credibility, transfrability, dependability, and confirmability

The results of this study can be concluded that: 1) The policy of the leader of the Islamic boarding school Hidayatul Mubtadi'in Kembang in the development of formal education is made in a way that is always side by side, in line and continues to collaborate with the school. the policies are

Email Addres: kamua975@gmail.com

LEADERSHIP: Jurnal Mahasiswa Manajemen Pendidikan is licensed under The CC BY License (https://creativecommons.org/licenses/by-sa/4.0/ ) 
LEADERSHIP, 2(1), Desember 2020, ISSN (online) : :2715-0399 I

ISSN (Print out) : 2721-7108

Homepage : http://e-journal.staima-alhikam.ac.id/index.php/mpi

DOI : : : : $\quad$ : $\quad$ 2478/leadership.v2i1. 585

Article type : Review Article

also very good, and very supportive of the existing programs in schools. Planning any policies before the start of each year of the education period. Planning references are the government's vision and mission, vision and mission of the institutions and pesantren programs. Policy efforts include meetings to evaluate development programs, strengthening collaboration, and building creativity and innovation in entrepreneurship. Policies are made on the basis of deliberation and the existence of responsible parties, namely caregivers, administrators, school principals and all WAKA, 2) The process of making policies for the leadership of the Hidayatul Mubtadi'in Kembang Islamic boarding school in the development of formal education, namely receiving input and suggestions by considering conditions and situations, communicate intensively, and use the alternative dar'ul mafasid muqoddamu 'ala jalbil masholih in the rules of ushul fiqh, accompanied by holding meetings and deliberations.

Keywords: Policy, Pesantren Leaders, Development, Formal Education

\begin{abstract}
Abstrak
Di lembaga-lembaga pendidikan baik formal maupun non-formal kebijakan seorang pemimpin menjadi pusat perbincangan dan perhatian dari para ahli, yaitu dari segi keilmuan itu sendiri dan ilmu lainnya. Berdasarkan fakta tersebut khususnya yang berhubungan dengan kebijakan pemimpin pondok pesantren mempunyai hak atas semua wewenang dan tanggung jawab yang ada di yayasan, terutama pada pendidikan formal dibawah naungannya. Oleh karena itu perlu untuk mengkaji kembali kebijakan pemimpin pondok pesantren dalam pengembangan pendidikan formal, sehingga dalam perkembangan pendidikan tidak hanya pada pendidikan pondok pesantren saja.

Berdasarkan kasus yang diambil, maka rumusan masalah penelitian adalah untuk mendiskripsikan bagaimana
\end{abstract}


LEADERSHIP, 2(1), Desember 2020, ISSN (online) : :2715-0399 I

ISSN (Print out) : 2721-7108

Homepage : http://e-journal.staima-alhikam.ac.id/index.php/mpi DOI : : : : $\quad$ : $\quad$ R2478/leadership.v2i1. 585

Article type : Review Article

kebijakan pemimpin pondok pesantren Hidayaul Mubtadi'in Kembang dalam pengembangan pendidikan formal, dan mendiskripsikan bagaimana proses pengambilan kebijakan pemimpin pondok pesantren Hidayaul Mubtadi'in Kembang dalam pengembangan pendidikan formal. Penelitian ini merupakan penelitian kualitatif. Pengumpulan data dilakukan dengan mengadakan observasi, wawancara dan dokumentasi. Analisis data dilakukan dengan pengumpulan data yang kemudian dipilih dan disederhanakan sesuai temuan penelitian, dengan melakukan penyajian data yang dapat ditarik kesimpulan. Adapun dalam penelitian ini teknik pengecekan keabsahan data yang digunakan adalah credibility, transfrability, ependadbility, dan confirmability.

Hasil penelitian ini dapat disimpulkan bahwa: 1) Kebijakan pemimpin pondok pesantren Hidayatul Mubtadi'in Kembang dalam pengembangan pendidikan formal, dibuat dengan cara selalu beriringan, sejalan dan terus berkolaborasi dengan pihak sekolah. kebijakannya juga sangat baik, dan sangat mendukung dengan adanya program-program yang ada di sekolah. Perencanaan kebijakan setiap sebelum awal tahun dari periode pendidikan. Acuan perencanaan adalah visi misi pemerintah, visi misi lembaga dan program-program pesantren. Upaya kebijakan meliputi pertemuan untuk evaluasi program pengembangan, penguatan berkolaborasi, dan pembentukan kretivitas dan inovatif dalam berwirausaha. Kebijakan dibuat atas dasar musyawarah dan adanya pihak yang bertanggung jawab yaitu pengasuh, pengurus, Kepala Sekolah dan semua WAKA, 2) Proses pengambilan kebijakan pemimpinan pondok pesantren Hidayatul Mubtadi'in Kembang dalam pengembangan pendidikan formal yaitu menerima masukan dan saran dengan mempertimbangkan kondisi dan situasi, melakukan komunikasi secara intensif, dan menggunakan alternatif dar'ul mafasid muqoddamu 'ala jalbil masholih dalam kaidah ushul fiqh, disertai dengan mengadakan pertemuan dan musyawarah. 
LEADERSHIP, 2(1), Desember 2020, ISSN (online) : :2715-0399 I

ISSN (Print out) : 2721-7108

Homepage : http://e-journal.staima-alhikam.ac.id/index.php/mpi

DOI : : : : $\quad$ : $\quad$ R2478/leadership.v2i1. 585

Article type : Review Article

Kata Kunci : Kebijakan, Pemimpin Pesantren, Pengembangan, Pendidikan Formal.

\section{A. PENDAHULUAN}

Pondok pesantren merupakan suatu lembaga pendidikan tradisional Islam yang masih terkenal dan ada sampai sekarang. Pada zaman moderen ini terjadi adanya pengaruh dari arus globalisasi yang menyebabkan perubahanperubahan sehingga mengakibatkan hilangnya kekhasan dari keberadaan suatu lembaga tradisional Islam. ${ }^{1}$ Di dalam pondok pesantren memiliki organisasi di bawah pemimpin pondok pesantren yang umum disebut dengan kiai atau pengasuh pondok pesantren.

Pemimpin pondok pesantren adalah seseorang yang mempunyai kewenangan untuk menentukan langkah-langakah dalam pengarahan gerak suatu pondok pesantren. ${ }^{2}$ Beliau merupakan tokoh demokrasi, otoriter dan menjadi pusat dari segala kebijakan. ${ }^{3}$ Adapun yang dimaksud dengan kebijakan adalah suatu tindakan yang dilakukan oleh seseorang yang mengarah pada tujuan atas usulan dan saran seseorang dengana adanya hambatan-hambatan guna pencapaian pada sasaran yang diinginkan. ${ }^{4}$

Munculnya masa tua ini pondok pesantren mengalami kecenderungan untuk mengukuhkan suatu organisasi kelembagaan, terutama pada unit kepemimpinan dan menejemen. Hal utama yang menjadi berkembangnya lembaga pondok pesantren ini disebabkan adanya suatu keberagaman pendidikan yang dilakukan, dan juga termasuk adanya madrasah dan sekolah formal yang menganut sistem rasional, demokrasi dan terbuka. ${ }^{5}$

\footnotetext{
${ }^{1}$ Nurcholis Madjid, Bilik-Bilik Pesantren: Sebuah Proses Perjalanan (Jakarta:

Paramadina,1997),3

${ }^{2}$ Mastuhu, "Kyai Tanpa Pesantren: KH. Ali Yafie dalam Peta Kekuatan Sosial Islam Indonesia”, dalam Jamal D. Rahman et al. (eds.), Wacana Baru Fiqh Sosial 70 Tahun KH. Ali Yafie (Bandung: Mizan Bekerjasama dengan Bank Muamalat Indonesia, 1997), 259

3 Hasbullah, Kapita Selekta Pendidikan Islam di Indonesia, Lintasan Sejarah Pertumbuhan Dan Perkembangan (Jakarta: Raja Grafindo Persada, 1996), 49

4 Sholichin Abdul Wahab, Analisis Kebijakan: dari Formulasi ke Implementasi Kebijakan Negara (Jakarta: Bumi Aksara, 1991), 13

5 Azyumardi Azra, "Pesantren: Kontinuitas dan Perubahan" Pengantar dalam Nurcholis Madjid, Bilik-Bilik Pesantren: Sebuah Proses Perjalanan (Jakarta: Paramadina, 1997), xx
} 
LEADERSHIP, 2(1), Desember 2020, ISSN (online) : :2715-0399 I

ISSN (Print out) : 2721-7108

Homepage : http://e-journal.staima-alhikam.ac.id/index.php/mpi

DOI : : : : $\quad$ : $\quad$ Review Articleadership.v2i1. 585

Article type : Review Article

Oleh karena itu, adanya pendidikan formal dalam pondok pesantren Hidayatul Mubtadi'in Kembang Singoari Malang menjadikan tugas pemimpin pondok pesantren semakin berat dan rumit. Sehingga perlu adanya pembentukan kepemimpinan dalam yayasan sesuai dengan tugas dan fungsi masing-masing untuk mengurus pelaksanaan pendidikan pondok pesantren maupun pendidikan formal.

Sehingga posisi seorang pemimpin di yayasan pesantren sebagai pengasuh, merupakan posisi tertinggi dalam penentuan dan pengambilan kebijakan, baik itu di pondok pesantren maupun di lembaga pendidikan formal, terutama kebijakan dalam pengembangan pendidikan formal.

\section{B. METODE PENELITIAN}

Penelitian ini menggunakan pendekatan kualitatif dan jenis penelitian ini merupakan studi kasus yang dilakukan dengan cara mengupas secara mendalam bagaimana kebijakan pemimpin pondok pesantren Hidayatul Mubtadi'in Kembang Singosari Malang dalam pengembangan pendidikan formal.

Dalam penelitian ini yang menjadi subyek penelitiannya adalah pengasuh pondok pesantren Hidayatul Mubtadi'in Kembang Singosari Malang sebagai informan utama, dan juga kepala sekolah SMP dan SMK, guru SMP dan SMK, ustadzah dan pengurus pondok pesantren Hidayatul Mubtadi'in Kembang Singosari Malang sebaagi informan tambahan.

Teknik pengumpulan data yang digunakan dalam penelitian ini yaitu dengan melalui observai, wawancara dan dokumentasi. Untuk menganalisis data menggunakan teknik kondensasi data, penyajian data dan penarik kesimpulan/verifikasi. Selain itu untuk mengetahui keabsahan data dalam penelitian yang dilakukan di pondok pesantren Hidayatul Mubtadi'in Kembang Singosari Malang menggunakan teknik credibility, transfrability, dependability, dan confirmability.

\section{LITERATURE REVIEW}

\section{Kebijakan}

\section{a. Pengertian Kebijakan}

Di dalam buku Efektivitas Kebijakan Pendidikan, Syafaruddin mendefinisikan kebijakan sebagai berikut:

Kebijakan (policy) secara etimologi (asal kata) diturunkan dari bahasa Yunani, yaitu "polis" yang artinya kota (city). Dapat ditambahkan, kebijakan mengacu kepada cara-cara 
LEADERSHIP, 2(1), Desember 2020, ISSN (online) : :2715-0399 I

ISSN (Print out) : 2721-7108

Homepage : http://e-journal.staima-alhikam.ac.id/index.php/mpi

DOI : : : : $\quad$ : $\quad$ Review Articleadership.v2i1. 585

Article type : Review Article

dari semua bagian pemerintahan mengarahkan untuk mengelola kegiatan mereka. Dalam hal ini, kebijakan berkenaan dengan gagasan pengaturan organisasi dan merupakan pola formal yang sama-sama diterima pemerintah atau lembaga sehingga dengan hal itu mereka beruaha mengejar tujuannya. ${ }^{6}$

Secara istilah, kebijakan merupakan suatu wujud dari asas sebuah rencana untuk melakukan suatu pekerjaan yang dibuat sepenuhnya secara rasional melalui optimalisasi strategi yang digunakan mencari alternatif terbaik pada rangka usaha pencapaian tujuan secara maksimum. ${ }^{7}$

Selain itu Friedrik dalam wahab juga mengatakan, kebijakan merupakan suatu tindakan yang dilakukan oleh seseorang yang mengarah pada tujuan atas usulan dan saran seseorang atau suatu kelompok dengana adanya hambatanhambatan guna pencapaian pada sasaran yang diinginkan. ${ }^{8}$

Melihat dari pengertian kebijakan yang disampaikan Friedrik, maka di dalam lembaga pendidikan yang termasuk juga di pondok pesantren kebijakan pemimpin harus selalu berpegangan teguh dengan visi dan misi lembaga. Sehingga kebijakan dapat diartikan sebagai kegiatan yang terarah, seperti halnya gambar 1

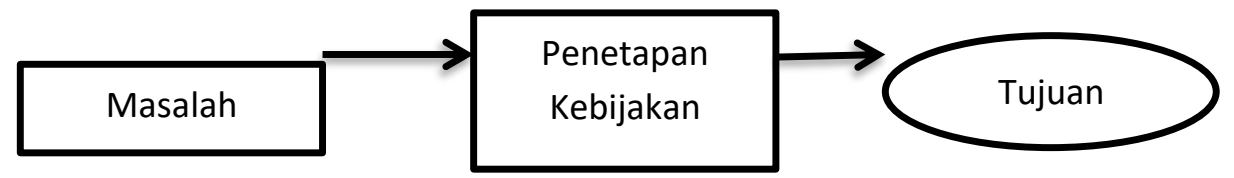

Gambar 1. Kebijakan merupakan tindakan yang terarah ${ }^{9}$

Yang dimaksud dengan penetapan kebijakan yaitu sebuah keputusan dari seorang pemimpin yang dibuat untuk menerima atau menolaknya. Dengan ini keputusan seorang pemimpin menjadikan keefektifan dari suatu kebijakan, karena dalam penetapan kebijakan diperlukan yang namanya pengenalan masalah, proses pengumpulan

\footnotetext{
${ }^{6}$ Syafaruddin, Efektivitas Kebijakan Pendidikan (Jakarta: Rineka Cipta, 2008), 75.

7 Sulthon Masyhud dan Moh. Khusnurdilo, Manajemen Pondok Pesantren (Jakarta:

Diva Pustaka, 2005), 47

8 Sholichin Abdul Wahab, Analisis Kebijakan: dari Formulasi ke Implementasi Kebijakan Negara (Jakarta: Bumi Aksara, 1991), 13

${ }^{9}$ Ibid.13
} 
LEADERSHIP, 2(1), Desember 2020, ISSN (online) : :2715-0399 I

ISSN (Print out) : 2721-7108

Homepage : http://e-journal.staima-alhikam.ac.id/index.php/mpi

DOI : : : : $\quad$ : $\quad$ R2478/leadership.v2i1. 585

Article type : Review Article

masalah, sampai adanya penetapan kebijakan yang dapat memberikan suatu jawaban dari adanya permasalahan yang ada.

\section{b. Tahap-Tahap Pembuatan Kebijakan}

Adapun proses kebijakan menurut William N. Dunn yaitu:

1) Penyusunan Agenda

Perumusan masalah ini adalah suatu tahapan yang sangat penting. Tahapan ini diawali dengan adanya identifikasi masalah. Tahapan ini disebut juga dengan penyusunan agenda (agenda setting). Dalam penyusunan agenda kebijakan ini didahului dengan munculnya suatu permasalahan di lingkungan masyarakat. ${ }^{10}$

2) Formulasi kebijakan

Formulasi kebijakan atau forecasting merupakan sebuah kegiatan dalam penentuan informasi factual yang berkaitan dengan situasi di masa depan dengan adanya informasi yang ada saat ini. ${ }^{11}$

3) Adopsi kebijakan

Adopsi kebijakan merupakan salah satu pilihan dari berbagai macam alternatif pemecahan yang diadopsi untuk memberikan solusi dari sebuah permasalahan tersebut. ${ }^{12}$

Adapun beberapa metode rekomendasi kebijakan diantaranya yaitu:

a) Metode Perbandingan

Dari semua kebijakan yang ada akan dibandingkan sesuai kriteria tertentu dan memilih salah satu dari alternatif kebijakan yang mempunyai nilai tinggi.

b) Metode Memuaskan

Yaitu alternatif yang dipilih sesuai dengan kemampuan yang memenuhi kriteria dari persyaratan yang ditetapkan, dan jika tidak ada kriteria alternatif yang memenuhi maka harus ada pengurangan alternatif sesuai kriteria yang ada.

c) Lexicographic Ordering Method

Dari semua alternatif kebijakan yang ada dibandingkan dan diurutkan berdasarkan kriteria yang paling penting.

\footnotetext{
${ }^{10}$ William Dunn, Pengantar Analisi Kebijakan, ter. Arrangement with prentice hall ( Yogyakarta: Gadjah Mada University Press, 1999), 97

${ }^{11}$ William N.Dunn, Pengantar Analisis Kebijakan Publik, cet ke-IV, (Yogyakarta: Gajah Mada University Press,2000), hal.27

${ }^{12}$ Muchlis Hamdi, Kebijakan Publik..., 77-79
} 
LEADERSHIP, 2(1), Desember 2020, ISSN (online) : :2715-0399 I

ISSN (Print out) : 2721-7108

Homepage : http://e-journal.staima-alhikam.ac.id/index.php/mpi

DOI : : : : $\quad$ : $\quad$ Review Article

Article type : Review Article

d) Non-Dominated Alternatives Method

Dari semua alternatif yang ada dievaluasi sesuai kriteria yang ditetapkan agar mengetahui tinggi rendahnya alternatif tersebut, apabila terdapat skor alternatif yang rendah maka harus disingkirkan dan alternatif yang lebih unggul dianalisis terlebih dulu.

4) Implementasi kebijakan

Implementasi kebijakan menurut Daniel A. Mazmaniah dan Paul Sabatier yang ada dalam Abdul Wahab yaitu suatu pemahaman dari kenyataan yang sudah diprogram perumusannya sehingga disebut dengan fokus perhatian implementasi kebijakan, dan yang merupakan suatu kejadian yang muncul setelah disahkan pedoman kebijakan Negara, yang meliputi usaha dalam administrasinya maupun untuk menimbulkan dampak pada masyarakat. ${ }^{13}$

Model-model implementasi kebijakan yang digariskan oleh persons yaitu: I) The Analysis of failure (model analisis kegagalan), 2) Model Rasional (top down) untuk mengidentiflkasi faktor-faktor mana yang membuat implementasi sukses, 3) Model pendekatan Buttom up kritikan terhadap model top down dalam kaitanya dengan faktor-faktor lain dan interaksi organisasi, 4) Teori-teori hasil sintesis (Hibrid teories). ${ }^{14}$

5) Evaluasi

Evaluasi merupakan kegiatan yang dilakukan untuk menilai tingkatan kinerja dari suatu kebijakan yang sudah berjalan dan mempunyai waktu yang cukup untuk dinilai, dan evaluasi ini tidak ada batasan waktu yang pasti kapannya akan dinilai kebijakan tersebut. ${ }^{15}$

\section{Pemimpin Pondok Pesantren}

\section{a) Pengertian Pemimpin Pondok Pesantren}

Pemimpin pondok pesantren adalah seorang pengasuh yang mempunyai kemampuan dalam mempengaruhi, memotivasi, mengarahkan, membimbing, memerintah, melarang bahkan memberi

\footnotetext{
${ }^{13}$ Abdul Wahab, S. Analisis Kebijakan : dari Formulasi ke Implementasi Kebijakan Negara ( Jakarta: Bumi Aksara,1991), hal.98

${ }^{14}$ Waine Parsons, Public Policy, Pengantar Teori dan Praktek Analisis Kebijakan, ter tri Wibowo Budi Santoso (Jakarta:Kencan Persada Media Group, 2006),463-472

15 Subarsono, Analisi Kebijakan Publik:Konsep,Teori dan Aplikasi (Yogyakarta: Pustaka Pelajar, 2015)
} 
LEADERSHIP, 2(1), Desember 2020, ISSN (online) : :2715-0399 I

ISSN (Print out) : 2721-7108

Homepage : http://e-journal.staima-alhikam.ac.id/index.php/mpi

DOI : : : : $\quad$ : $\quad$ R2478/leadership.v2i1. 585

Article type : Review Article

kebijakan dan hukuman terhadap pengikutnya yang ada di pondok pesantren berdasarkan perspektif Islam.

\section{b) Fungsi Kepemimpinan}

Fungsi kepemimpinan menurut Sondang P. Sagian terdiri dari: 1) pemimpin sebagai penentu arah, 2) wakil dan juru bicara, 3) sebagai komunikator yang aktif, 4) sebagai mediator, 5) dan integrator. ${ }^{16}$ Selain itu menurut Hadar Nawawi, fungsi dari kepemimpinan meliputi: ${ }^{17}$

1) Pengambil keputusan

2) Fungsi instruksi (perintah)

3) Fungsi konsulatif

4) Fungsi parsipatif

5) Fungsi delegatif

c) Teori Kepemimpinan

Terdapat beberapa teori kepemimpinan yang harus dimiliki oleh seorang pemimpin itu sendiri diantaranya adalah:
1) Teori sifat
2) Teori prilaku
3) Teori tiga dimensi
4) Teori situsional ${ }^{18}$

\section{d) Gaya Kepemimpinan Kiai}

Seorang pemimpin merupakan panutan yang tentunya baik dan bertanggung jawab. Di dalam Al-Qur'an dan Hadits juga sudah diterangkan bahwa terdapat empat sifat yang harus dimiliki para nabi sebagai pemimpin umatnya. Dan diantara empat sifat tersebu yaitu Ash-Shidiq (benar), Al-Amanah (dipercaya), At-Tabllig (menyampaikan), Al-Fathanah (cerdas).

\section{Pengembangan}

Pengembangan merupakan usaha dalam pendidikan formal dan non-formal yang dilakukan dalam kondisi sadar, teratur, berencana, terarah dan bertanggung jawab dalam program perkenalan, pertumbuhan, bimbingan dan mengembangkan pada kepribadian yang

\footnotetext{
${ }^{16}$ Sondang P. Sagian, Teori dan Praktek Kepemimpinan (Jakarta: PT Bina Aksara, 1999), 46-50

${ }^{17}$ Haidar Nawawi, Kepemimpinan..., 46-59

18 Viethzal Rivai dan Sylviana Murni, Education Manajemen: Analisi Teori dan Praktik, (Jakarta: Rajawali Pers, 2009), hal.287-288
} 
LEADERSHIP, 2(1), Desember 2020, ISSN (online) : :2715-0399 I

ISSN (Print out) : 2721-7108

Homepage : http://e-journal.staima-alhikam.ac.id/index.php/mpi

DOI : : : : $\quad$ : $\quad$ Review Articleadership.v2i1. 585

Article type : Review Article

imbang, utuh dan merata, kreatifitas dan pengetahuan yang sama dengan bakatnya, kemauan dan kemampuan yang selanjutnya dapat dijadikan modal dalam meningkatkan dan mengembangkan diri untuk mencapai pada tingkatan kedudukannya, kualitas dan kecakapan manusia yang optimal dan mandiri. ${ }^{19}$

\section{Pendidikan Formal}

\section{a. Pengertian Pendidikan Formal}

pendidikan formal merupakan kegiatan dalam pembelajaran yang diselenggarakan secara tersistem, terstruktur dan berjenjang, yang dimulai dari tingkat pendidikan dasar sampai pendidikan tertinggi yaitu mulai dari pendidikan SD, SMP, SMK, sampai perguruan tinggi. ${ }^{20}$

b. Fungsi Lembaga Pendidikan

Terdapat beberapa fungsi utama yang telah dijabarkan dalam pengembangan pendidikan formal, yaitu:

1) Melanjutkan kebudayaan melalui pewarisan pada generasi satu ke generasi yang lain

2) Memperkarya kehidupan dengan membuat peluang dalam perkembangan pengetahuan intelek, citra rasa keindahan para siswa

3) Menciptakan kepribadian siswa untuk menjadi anggota masyarakat yang baik.

\section{HASIL DAN PEMBAHASAN}

Berdasarkan penelitian tentang kebijakan pemimpin pondok pesantren Hidayatul Mubtadi'in Kembang Singosari Malang dalam pengembangan pendidikan formal ini telah memberikan penjelasan bagaimana kebijakan dan proses pengambilan kebijakan pemimpin pondok pesantren Hidayatul Mubtadi'in Kembang Singosari Malang dalam pengembangan pendidikan formal. Berdirinya suatu pendidikan formal di bawah naungan pondok pesantren Hidayatul Mubtadi'in Kembang, maka setiap hal apapun tentu harus ada penyesuaian antara sekolah dengan pondok pesantren. Penyesuaian ini ada karena dengan adanya pendidikan formal di lingkungan pondok pesantren supaya tidak sampai menghilangkan tradisi dari pesantren itu sendiri.

19 Iskandar Wiryokusumo ddk, Kumpulan-KumpulanPemikiran dalam Pendidikan (Jakarta: CV. Rajawali, 1982), 93.

${ }^{20}$ Aida Mj, Ilmu Pendidikan (Semarang:Putra Sanjaya,2005), 67. 
LEADERSHIP, 2(1), Desember 2020, ISSN (online) : :2715-0399 I

ISSN (Print out) : 2721-7108

Homepage : http://e-journal.staima-alhikam.ac.id/index.php/mpi

DOI : : 10.32478/leadership.v2i1. 585

Article type : Review Article

Oleh karena itu dalam pengembangan pendidikan formal pemimpin pondok pesantren selalu membuat kebijakan secara beriringan, sejalan dan terus berkolaborasi dengan pihak lembaga pendidikan formal. Dengan tujuan agar semua kegiatan yang ada di pondok pesantren dan lembaga pendidikan formal tidak bertentangan, sehingga kebijakan pemimpin pondok pesantren yang dibuat dalam pendidikan formal sangatlah tepat dengan program yang ada di pondok pesantren. Sebagaimana sesuai pernyataan dari kepala sekolah SMK hidayaul Mubtadi'in Kembang :

"Berkaitan dengan kebijakan pengasuh dalam pengembangan pendidikan formal maka pengasuh dalam membuat kebijakan-kebijakan tersebut tentunya pasti sejalan, seiring dan terus berkolaborasi antara pihak SMK dan pondok, karena dalam kebijakan tersebut saling berhubungan. Namun dalam kebijakan yang berkaitan dengan formal tidaklah semua dari pengasuh. Selanjutnya untuk kebijakan pesantren dengan adanya pendidikan formal memang terdapat beberapa perubahan". ${ }^{21}$

Berkaitan dengan kepemimpinan yang mempunyai fungsi dalam kebijakan, seorang pemimpin merupakan suatu panutan bagi bawahanya. Sehingga dalam pencapaian tujuan organisasi pemimpin dapat memberikan arahan sebaik-baik mungkin. Begitu juga seorang pemimpin pondok pesantren yang memiliki kewenangan atas suatu kebijakan, terutama kebijakan dalam pengembangan pendidikan formal di pondok pesantren Hidayatul Mubtadi'in Kembang.

Kebijakan pemimpin pondok pesantren dalam pengembangan pendidikan formal di pondok pesantren Hidayatul Mubtadi'in Kembang sudah sangat baik dan pemimpin pesantren sangat memberikan dukungan dengan adanya pendidikan formal, sehingga pemimpin pondok pesantren memberikan banyak kebijakan dalam program pengembangan tersebut. Dan untuk perencanaan suatu kebijakan pemimpin pondok pesantren dilakukan tiap sebelum awal tahun dalam periode pendidikan. Sebagaimana pernyataan dari pemimpin pondok pesantren:

"Biasanya dalam pembuatan kebijakan dilakukan adanya perencanaan yaitu ketika kita akan memasuki periode baru dari sebuah periode pendidikan dan setiap tahun ada jenjang

${ }^{21}$ Joko Salam, Wawancara (Malang, 17 Juni 2020) 
LEADERSHIP, 2(1), Desember 2020, ISSN (online) : :2715-0399 I

ISSN (Print out) : 2721-7108

Homepage : http://e-journal.staima-alhikam.ac.id/index.php/mpi DOI : : : : $\quad$ : $\quad$ Review Articleadership.v2i1. 585

Article type : Review Article

pendidikan dan juga kita mempelajari kebijakan dari Kementerian Pendidikan dari Pemerintah seperti apa peraturan dan sebagainya hal-hal yang berkaitan dengan pendidikan tentu kita sesuaikan semaksimal mungkin, karena bagaimanapun kita dituntut untuk menciptakan generasi yang berkualitas, yang unggul dalam banyak hal". ${ }^{22}$

Selain adanya perencanaan pemimpin pondok pesantren juga membuat acuan dalam perencanaan program dalam pengembangan pendidikan formal SMK Hidayatul Mubtadi'in. Acuan perencanaan ini diperlukan karena merupakan pola dasar untuk menafsirkan hal apa saja yang akan ditetapkan terlebih dahulu sebelum terbentuknya kebijakan tersebut. Acuan dalam perencanaan program pengembangan pendidikan tersebut sesuai visi misi pemerintah, visi misi lembaga dan program-program pesantren. Seperti yang sudah disampaikan pemimpin pondok pesantren yaitu:

"Untuk acuan dalam pengembangan tentu visi misi Pemerintah itu yang pertama dan visi misi dari lembaga kita sendiri". 23

Terdapat pula upaya kebijakan pemimpin pondok pesantren Hidayatul Mubtadi'in dalam pengembangan pendidikan formal yaitu dengan mengadakan pertemuan untuk evaluasi tiap adanya program yang ada, mendorong untuk tetap berkoordinasi antar pihak, memberikan arahan untuk siswa tetap kreatif dan inovatif dalam berwirausaha, dan selain itu pemimpin pesantren memberikan banyak peluang agar anak dapat mengembangkan bakat sebagai siswa maupun santri. Dan kebijakan dibuat secara musyawarah dan pihak yang bertanggung jawab adalah pengasuh, pengurus, Kepala Sekolah dan semua WAKA.

Adapun proses pengambilan kebijakan pemimpin pondok pesantren Hidayatul Mubtadi'in Kembang Singosari dalam pengembangan pendidikan formal yaitu berdasarkan gambaran dari proses kebijakan William N. Dunn yaitu: penyususnan agenda, formulasi kebijakan, adopsi kebijakan, implementasi kebijakan, evaluasi kebijakan. Dan pemimpin pondok pesanrtn Hidayatul Mubtadi'in Kembang Singosari melakukan tahapan awal dengan

\footnotetext{
${ }^{22}$ Nur Muhammad, Wawancara (Malang, 28 Juni 2020)

${ }^{23}$ Nur Muhammad, Wawancara (Malang, 28 Juni 2020) 
LEADERSHIP, 2(1), Desember 2020, ISSN (online) : :2715-0399 I

ISSN (Print out) : 2721-7108

Homepage : http://e-journal.staima-alhikam.ac.id/index.php/mpi

DOI : : 10.32478/leadership.v2i1. 585

Article type : Review Article

menerima masukan dan saran dengan mempertimbangkan kondisi dan situasi. Pada tahapan awal ini merupakan perumusan masalah yang merupakan suatu tahapan yang sangat penting. Tahapan ini diawali dengan adanya identifikasi masalah. ${ }^{24}$

Langkah kedua pemimpin pondok pesantren melakukan komunikasi secara intensif yang merupakan formulasi kebijakan atau forecasting yaitu sebuah kegiatan dalam penentuan informasi faktual yang berkaitan dengan situasi di masa depan dengan adanya informasi yang ada saat ini. ${ }^{25}$

Langkah ketiga dilanjutkan dengan tahap adopsi kebijakan yaitu memilih dari salah satu banyaknya alternatif pemecahan yang ada untuk menyelesaikan dan memberikan solusi dari sebuah permasalahan. Selain itu untuk memilih alternatif kebijakan diperlukan perhatian yang sangat cermat supaya policy maker dijauhkan dari pilihan yang hanya untuk kepentingan pribadi. ${ }^{26}$ Dalam adopsi kebijakan ini pemimpin pondok pesantren Hidayatul Mubtadi'in Kembang menggunakan alternatif dar'ul mafasid muqaddamu 'ala jalbil masholih dalam kaidah ushul fiqh, sebagaimana hasil wawancara peneliti kepada pemimpin pondok pesantren sebagai berikut:

"Tentu sebuah kebijakan apapun pasti membawa maslahat dan beberapa pihak yang enggan mengikuti visi misi kita, hingga bagi mereka menjadi mafsadah dan tentu bagaimanapun yang kita ikuti adalah jalbil masholih dalam kaidah ushul fiqh dar'ul mafasid muqaddamu 'ala jalbil masholih, dan itu kaidah yang kita ikuti, jadi bagaimana juga mencegah kemudaratan diutamakan dibanding mengambil manfaat dari sesuatu itu kaidah ushul figh yang senantiasa kita pakai. memang sebuah kebijakan tidak bisa menguntungkan semua pihak tapi kalau terpaksa diambil salah satu ,maka itu landasan dari pola pikir kita". ${ }^{27}$

Dari penulis berpendapat bahwa adanya dar'ul mafasid muqaddamu 'ala jalbil masholih dalam kaidah ushul fiqh merupakan altrnatif yang dipilih berdasarkan metode Lexicographic Ordering Method yaitu Dari semua

${ }^{24}$ William Dunn, Pengantar Analisi Kebijakan , ter. Arrangement with prentice hall ( Yogyakarta: Gadjah Mada University Press, 1999), 97

25 Subarsono, Analisis Kebijakan Publik: Konsep, Teori dan Apliasi (Yogyakarta: Pustaka Pelajar, 2015), hal.37

${ }^{26}$ Muchlis Hamdi, Kebijakan Publik..., 77-79

${ }^{27}$ Nur Muhammad, Wawancara (Malang, 28 Juni 2020) 
LEADERSHIP, 2(1), Desember 2020, ISSN (online) : :2715-0399 I

ISSN (Print out) : 2721-7108

Homepage : http://e-journal.staima-alhikam.ac.id/index.php/mpi

DOI : : : : $\quad$ : $\quad$ Review Article

Article type : Review Article

alternatif kebijakan yang ada dibandingkan dan diurutkan berdasarkan kriteria yang paling penting. ${ }^{28}$ Dan untuk pembahasan ini pemimpin pondok pesantren dalam mengambil kebijakan lebih mengutamakan mencegah kemudaratan dibanding mengambil manfaat dari sesuatu.

Selanjutnya implementasi kebijakan pemimpin pesantren juga sudah baik, penerapannya pun dilakukan melalui perantara kepala sekolah yang kemudian langsung disampaikan kepada pihak lain yang bersangkutan dalam pelaksanaan kebijakan tersebut. Sedangkan untuk evaluasi juga dilakukan tiap satu bulan dua kali pertemuan dengan mengadakan rapat bersama pihak-pihak yang bersangkutan.

\section{E. KESIMPULAN}

Berdasarkan temuan dari hasil penelitian melalui observasi, wawancara dan dokumentasi tentang kebijakan pemimpin pondok pesantren Hidayatul Mubtadi'in Kembang Singosari dapat disimpulkan sebagai berikut:

1. Kebijakan pemimpin pondok pesantren Hidayatul Mubtadi'in Kembang Singosari dalam pengembangan pendidikan formal, dibuat dengan cara selalu beriringan, sejalan dan terus berkolaborasi dengan pihak sekolah. Selain itu pemimpin pondok pesantren dalam kebijakannya juga sangat baik, dan sangat mendukung dengan adanya program-program yang ada di sekolah, selama tidak bertentangan dengan kegiatan di pondok pesantren. Untuk perencanaan kebijakan pemimpin pondok pesantren dilaksanakan setiap sebelum awal tahun dari periode pendidikan. Dalam perencanaan kebijakan tersebut berpacu pada visi misi pemerintah, visi misi lembaga dan program-program pondok pesantren. Pemimpin pondok pesantren juga membuat upaya-upaya kebijakan meliputi pertemuan untuk evaluasi program pengembangan, penguatan berkolaborasi, dan pembentukan kretivitas dan inovatif dalam berwirausaha. Dan semua kebijakan pemimpin pondok pesantren dibuat atas dasar musyawarah dan adanya pihak yang bertanggung jawab yaitu pengasuh, pengurus, Kepala Sekolah dan semua WAKA

2. Proses Pengambilan Kebijakan Pemimpinan Pondok Pesantren Hidayatul Mubtadi'in Kembang Singosari Dalam Pengembangan Pendidikan Formal yaitu dengan mengawali menerima masukan dan saran dengan mempertimbangkan kondisi dan situasi suatu lembaga. Selanjutnya pemimpin pesantren melakukan komunikasi secara intensif dengan semua

${ }^{28}$ Muchlis Hamdi, Kebijakan Publik..., 77-79 
LEADERSHIP, 2(1), Desember 2020, ISSN (online) : :2715-0399 I

ISSN (Print out) : 2721-7108

Homepage : http://e-journal.staima-alhikam.ac.id/index.php/mpi

DOI : : 10.32478/leadership.v2i1. 585

Article type : Review Article

pihak yang bersangkutan. Selain itu pemimpin pondok pesantren dalam pengambilan kebijakan menggunakan alternatif dar'ul mafasid muqaddamu 'ala jalbil masholih dalam kaidah ushul figh, disertai dengan mengadakan pertemuan dan musyawarah.

\section{REFERENSI}

Azra Azyumardi, 1997, "Pesantren: Kontinuitas dan Perubahan" Pengantar dalam Nurcholis Madjid, Bilik-Bilik Pesantren: Sebuah Proses Perjalanan ,Jakarta: Paramadina

Dunn William, 1999, Pengantar Analisi Kebijakan, ter. Arrangement with prentice hall, Yogyakarta: Gadjah Mada University Press

Hamdi Muchlis, Kebijakan Publik

Hasbullah, 1996, Kapita Selekta Pendidikan Islam di Indonesia, Lintasan Sejarah Pertumbuhan Dan Perkembangan ,Jakarta: Raja Grafindo Persada

Madjid Nurcholis,1997, Bilik-Bilik Pesantren: Sebuah Proses Perjalanan, Jakarta: Paramadina

Mastuhu, 1997, "Kyai Tanpa Pesantren: KH. Ali Yafie dalam Peta Kekuatan Sosial Islam Indonesia", dalam Jamal D. Rahman et al. (eds.), Wacana Baru Fiqh Sosial 70 Tahun KH. Ali Yafie ,Bandung: Mizan Bekerjasama dengan Bank Muamalat Indonesia

Masyhud Sulthon dan Moh. Khusnurdilo, 2005, Manajemen Pondok Pesantren, Jakarta: Diva Pustaka

Mj Aida,2005, IImu Pendidikan, Semarang: Putra Sanjaya

Parsons Waine, 2006, Public Policy, Pengantar Teori dan Praktek Analisis Kebijakan, ter tri Wibowo Budi Santoso, Jakarta:Kencan Persada Media Group

Rivai Viethzal dan Sylviana Murni, 2009, Education Manajemen: Analisi Teori dan Praktik, Jakarta: Rajawali Pers 
LEADERSHIP, 2(1), Desember 2020, ISSN (online) : :2715-0399 I

ISSN (Print out) : 2721-7108

Homepage : http://e-journal.staima-alhikam.ac.id/index.php/mpi

DOI : : : : $\quad$ : $\quad$ R2478/leadership.v2i1. 585

Article type : Review Article

Sagian Sondang P, 1999, Teori dan Praktek Kepemimpinan, Jakarta: PT Bina Aksara

Subarsono, 2015, Analisis Kebijakan Publik: Konsep, Teori dan Apliasi, Yogyakarta: Pustaka Pelajar

Syafaruddin, 2008, Efektivitas Kebijakan Pendidikan, Jakarta: Rineka Cipta

Wahab Sholichin Abdul, 1991, Analisis Kebijakan: dari Formulasi ke Implementasi Kebijakan Negara, Jakarta: Bumi Aksara

Wahab, Abdul S,1991. Analisis Kebijakan : dari Formulasi ke Implementasi Kebijakan Negara, Jakarta: Bumi Aksara

Wiryokusumo Iskandar ddk, 1982, Kumpulan-KumpulanPemikiran dalam Pendidikan ,Jakarta: CV. Rajawali 